Canadian Journal of Fisheries and Aquatic Sciences, 49 (6): pp. 1216-1227 (1992).

http://pubs.nrc-cnrc.gc.ca/eng/home.html

http://article.pubs.nrc-

cnrc.gc.ca/RPAS/rpv?hm=HInit\&calyLang=eng\&journal=cjfas\&volume=49\&afpf=f92-

137.pdf

ISSN: $1205-7533$

DOI: $10.1139 / \mathrm{f} 92-137$

(C) National Research Council of Canada. 


\title{
Complex Interactions between Fish and Zooplankton: Quantifying the Role of an Open-Water Planktivore
}

\author{
Dennis R. DeVries ${ }^{1}$ and Roy A. Stein \\ Aquatic Ecology Laboratory, Department of Zoology, The Ohio State University, Columbus, OH 43212, USA
}

\begin{abstract}
DeVries, D. R., and R. A. Stein. 1992. Complex interactions between fish and zooplankton: quantifying the role of an open-water planktivore. Can. J. Fish. Aquat. Sci. 49: 1216-1227.

An open-water planktivore, the gizzard shad (Dorosoma cepedianum), can drive complex interactions among fish and zooplankton in Ohio reservoirs. In Kokosing Lake, crustacean zooplankton density declined to near zero immediately after larval gizzard shad abundance peaked during 1987 and 1988 . This decline can be attributed to increased death rates, due to predation, and to reduced number of eggs per cladoceran. In an enclosure/ exclosure experiment, young-of-year gizzard shad at lake densities significantly reduced density of crustacean zooplankton and rotifers within 2 wk. In addition, phytoplankton that were edible to zooplankton were reduced in enclosures, likely due to a combination of direct herbivory by gizzard shad and reduced nutrient availability due to uptake by the growing gizzard shad. Gizzard shad not only directly influenced zooplankton via predation, they also indirectly affected zooplankton by reducing phytoplankton abundance. Because larval bluegill (Lepomis macrochira) migrated to the limnetic zone during or shortly after the zooplankton decline, food available to these zooplanktivorous larvae, as well as their ultimate recruitment, was reduced with gizzard shad. Through direct (i.e. predation) and indirect (i.e. influencing algal abundance) pathways, gizzard shad can drive zooplankton to extinction, thereby reducing recruitment of other fishes and controlling community composition.
\end{abstract}

Un planctonophage de mer libre, l'alose à gésier (Dorosoma cepedianum) peut causer des interactions complexes entre les poissons et le zooplancton dans des bassins de l'Ohio. Dans le lac Kokosing, la densité du zooplancton composé de crustacés a chuté à presque zéro juste après que la population de larves d'aloses à gésier a atteint un sommet au cours des années 1987 et 1988. Cette diminution peut être attribuée à un taux de mortalité acctu, en raison de la prédation et du nombre réduit d'oeufs par cladocère. Dans une expérience comparative enclos/ hors enclos, de jeunes aloses à gésier de l'année en densité comparable à celle des populations lacustres, ont fait diminuer de façon importante la densité du zooplancton de crustacés et celle des rotifères en moins de deux semaines. En outre, le phytoplancton qui sert de nourriture au zooplancton a diminué dans les enclos, probablement en raison de deux phénomènes conjugués : l'alose à gésier en a consommé directement, et elle a également ingéré des matières nutritives pendant sa croissance, réduisant ainsi la quantité de nourriture disponible pour le phytoplancton. L'alose à gésier a nui au zooplancton non seulement de façon directe, par prédation, mais aussi indirectement, en réduisant la densité du phytoplancton. Étant donné que les larves de branchie bleue (Lepomis macrochira) migrent vers la zone limnétique lorsque le zooplancton se fait plus rare, ou peu après cette baisse, l'alose à gésier a provoqué une diminution de la nourriture disponible pour ces larves zooplanctonivores, de même qu'un déclin de leur recrutement final. De façon directe (c'est-à-dire par la prédation) et indirecte (en modifiant la concentration algale), l'alose à gésier peut provoquer la disparition du zooplancton, réduisant ainsi le recrutement d'autres poissons et limitant la composition de la communauté.

Received lune 19, 1991

Accepted December 16, 1991

(JB091)
Reçu le 19 juin 1991

Accepté le 16 décembre 1991
$\mathbf{P}$ redators can dramatically influence aquatic communities, both directly and indirectly (see chapters in Kerfoot and Sih 1987; Carpenter 1988; Ebenman and Persson 1988). By removing prey, predators directly alter community species composition. Indirect effects of predators can take several forms, leading to positive (e.g. Kerfoot 1987) as well as negative (e.g. Mittelbach and Chesson 1987) effects for prey. The current focus within ecology on biomanipulation, applying the cascading trophic interactions hypothesis (Shapiro and Wright 1984; Carpenter et al. 1985; McQueen et al. 1989; Gophen 1990; McQueen 1990) as a tool to influence water quality, emphasizes the indirect impacts that predators can have on entire lake ecosystems, with effects of predation extending beyond adjacent trophic levels.

\footnotetext{
'Present address: Department of Fisheries and Allied Aquacultures, Auburn University, Auburn, AL 36849, USA.
}

Systemwide effects of predators have been well described for planktivore-plankton interactions (see reviews in Hall et al. 1976; Greene 1985; Lazzaro 1987; Northcote 1988; Gliwicz and Pijanowska 1989). In general, planktivorous fishes remove large zooplankters (e.g. Brooks and Dodson 1965), and invertebrates remove small forms (e.g. Wong 1981; Dodson 1974). The conventional model states that when planktivorous fish occur in a lake, large zooplankters are selectively removed and smaller forms dominate (e.g. Brooks and Dodson 1965; Wells 1970; Warshaw 1972; Evans 1986). Furthermore, because vertebrate predators select large prey, they also will remove invertebrate predators, which tend to be large, reducing their predation on small zooplankton and reinforcing the dominance of small forms (Dodson 1970, 1974). Without fish, competitive interactions among plankters are complex, influenced by body size and environmental conditions (Bengtsson 1987; DeMott 
1989); however, because invertebrate predators can survive and remove small zooplankters (Lynch 1979), large forms tend to predominate.

Studies detailing these interactions typically have involved adult fishes; however, larvae of most fishes also feed on zooplankton (e.g. Applegate and Mullan 1967; Werner 1969; Keast 1980; Whiteside et al. 1985a, 1985b; Whiteside 1989) and can be important regulators of zooplankton abundance (Doolittle 1982; Whiteside et al. 1985b; Cryer et al. 1986; Mills et al. 1987; Whiteside 1989). Unlike adults, larval planktivores are gape-limited predators, initially removing small plankters and including larger prey as they grow and their gape increases (Rosenthal and Hempel 1970; Wong and Ward 1972; Zaret 1980; Hansen and Wahl 1981). Seasonality in fish spawning produces pulses of larval planktivores resulting in seasonal impacts on zooplankton. In addition, fishes may exhibit ontogenetic niche shifts to or from planktivory (Mittelbach 1981; Werner et al. 1983; Werner and Gilliam 1984), providing additional temporal variability in predation pressure on zooplankton. In turn, because year-class strength in most fishes is set during early life history (Cushing 1975; Lasker 1975; Ware 1980; Mills and Forney 1988), survival through the larval stage is critical to recruitment. Consequently, understanding the larval fish - zooplankton interaction contributes to understanding the mechanisms underlying adult population size (as well as the role of larval fishes in biomanipulation) and provides insight into community composition in lakes.

As planktivores, gizzard shad (Dorosoma cepedianum), which dominate the planktivore biomass of many central and southern U.S. lakes and reservoirs (Jenkins 1967; Timmons et al. 1978; Johnson et al. 1988), can influence zooplankton dynamics. Using experiments in ponds and laboratory pools, Drenner and his colleagues have documented that adult gizzard shad reduce densities of most easily captured zooplankters (Drenner et al. 1978, 1982a, 1982b, 1986; Drenner and McComas 1980; Threlkeld and Drenner 1987) and influence phytoplankton community structure (Drenner et al. 1984, 1986). All studies to date, however, have dealt with fish $>50 \mathrm{~mm}$ (total length), providing no information on effects of particulate-feeding larvae.

Herein, we quantify how young-of-year gizzard shad $(<50 \mathrm{~mm})$ influence reservoir community structure, as mediated through their influence on zooplankton. We first document zooplankton and larval gizzard shad abundance patterns in an Ohio reservoir, suggesting two hypotheses to explain these patterns. Then, we describe an enclosure/exclosure experiment designed to test the validity of these hypotheses. Our results suggest that young-of-year gizzard shad can be important regulators of zooplankton, via a combination of the direct effects of predation and indirect effects on phytoplankton. Finally, we explore how gizzard shad - zooplankton interactions influence other species with zooplanktivorous larvae.

\section{Methods}

\section{Study Lake}

Kokosing Lake (Knox County, central Ohio) is a 65-ha shallow (mean depth $=2.0 \mathrm{~m}$, maximum depth $=4.9 \mathrm{~m}$ ), flood control impoundment with $7.5 \mathrm{~km}$ of shoreline and Secchi depths typically $<1 \mathrm{~m}$. Neither submersed nor emergent vegetation is abundant. The fish community consists of gizzard shad, largemouth bass (Micropterus salmoides), white crappie (Pomoxis annularis), bluegill (Lepomis macrochira; Bailey and Robins 1988), and common carp (Cyprinus carpio).

\section{Field Sampling Methods}

Larval fish were collected in two replicate daytime surface tows with a 0.75 -m-diameter ichthyoplankton net $(2 \mathrm{~m}$ long, $500-\mu \mathrm{m}$ mesh) towed in the limnetic zone at $\geqslant 1.5 \mathrm{~m} / \mathrm{s}$ once per week during April through September 1986-89. We used a flowmeter mounted in the mouth of the net to calculate volume of water filtered. Larvae were preserved in formalin and returned to the laboratory where they were identified, measured (nearest millimetre, up to 50 per species), and their diets quantified (1-10 individuals per species per date, minimum number determined by availability of larvae in samples). Cladocerans and rotifers were identified to genus, and copepods were classified as nauplii, calanoids, or cyclopoids. All prey were measured (nearest $0.1 \mathrm{~mm}$ ) and lengths were converted to biomass using taxon-specific length - dry weight regressions (G. G. Mittelbach, unpubl. data). Integrated zooplankton samples (four columns per sample, three replicate samples per date) were collected each week during April through September 1987 and 1988 using a $2-\mathrm{m}$ tube sampler $(7.30-\mathrm{cm}$ inside diameter, 54- $\mu \mathrm{m}$ mesh; DeVries and Stein 1991) simultaneous with larval fish collection. Samples were preserved in 5\% sucrose formalin (Haney and Hall 1973) and returned to the laboratory. When fewer than 200 individuals per taxon were captured, all were counted in the sample; $10 \%$ subsamples were counted for abundant taxa until at least 200 individuals were counted. At least 20 individuals of each taxon in a sample were measured (nearest $0.1 \mathrm{~mm}$ ) using a drawing tube and digitizing tablet. Cladocerans were measured from the anterior portion of the carapace to the base of the basal spine; copepods were measured from the anterior portion of the carapace to the base of the caudal rami. Number of individuals carrying eggs out of 50 randomly chosen individuals and the clutch size for 20 individuals carrying eggs were recorded for Bosmina and Daphnia (the dominant cladocerans) for four to six dates during and after the crustacean zooplankton decline.

To evaluate the potential for competition between larval bluegill and larval gizzard shad that cooccurred in the limnetic zone (larval bluegill spend several weeks in the limnetic before returning to the littoral zone, Werner 1967; Storck et al. 1978), we used Schoener's overlap index (Schoener 1970) based on the average proportion that each prey taxon contributed to total biomass in iarval fish diets (i.e. the proportion was calculated within each fish and averaged across fish within a date, Wallace 1981). The formula for this index is

$$
\text { Overlap }=1-0.5\left(\sum_{i=1}^{n}\left|r_{x i} \cdot r_{y i}\right|\right)
$$

where $r_{x i}$ and $r_{y i}=$ the proportions of prey type $i$ in the diets of species $x$ and $y$, respectively, and $n=$ number of food categories. This index ranges from 0 to 1 , with 0 representing no diet overlap and 1 indicating complete diet overlap. Because larval fish and zooplankton communities changed through time, we treated overlap measures calculated for each sample date as replicates.

To evaluate prey selection by fishes, we compared larval fish diets with zooplankton samples using Chesson's alpha (Chesson 1978, 1983), treating individual fish as replicates within each date. The formula for this index is

$$
\alpha=\frac{r_{i} / p_{i}}{\sum_{i}\left(r_{i} / p_{i}\right)}, \quad i=1, \ldots, m
$$


where $p_{i}=$ the proportion of prey item $i$ in the environment (i.e. the lake), $r_{i}=$ the proportion of prey item $i$ in the fish's diet, $m=$ the number of prey items in the environment, and $\alpha=$ the selectivity. With this index, a value of $\alpha=(1 / \mathrm{m})$ occurs when a prey item is consumed in propotion to its abundance in the environment; values $>1 / m$ indicate preference and values $<1 / m$ indicate avoidance.

\section{Enclosure/Exclosure Experiment}

To quantify the impact of larval gizzard shad on zooplankton community structure, we conducted an enclosure/exclosure experiment in Kokosing Lake during 6 June through 5 July 1988. Twelve polyethylene bags (1.13-m diameter, $2 \mathrm{~m}$ deep, $2-\mathrm{m}^{3}$ volume; not in contact with the sediment, bags were sealed at the bottom) were filled with lake water from a depth of $1 \mathrm{~m}$ using a large water pump (3.8- $\mathrm{cm}$ hose diameter, $189 \mathrm{~L} / \mathrm{min})$ on 16-17 May 1988 (just before larval gizzard shad were first collected in the limnetic zone). On 6 June 1988, larval gizzard shad were collected at night by attracting them to lights (Gregory and Powles 1985) and stocked into six randomly chosen bags at a density of $120 \mathrm{fish} / \mathrm{bag}$. Mean size of stocked fish was $18.4 \pm 0.4 \mathrm{~mm}$ total length (TL) (mean $\pm 1 \mathrm{SE}, n=38$ ). To estimate mortality due to handling of stocked larval gizzard shad, we introduced 50 fish into each of two containers (about $200 \mathrm{~L}$ ) floating next to the bags. The next day, these containers were drained; surviving fish were counted and measured. Survival of stocked gizzard shad larvae, based on survival in our holding containers, was $32 \%$ (range $29-35 \%, n=2$ ), yielding a stocking density of $19.4 \mathrm{fish} / \mathrm{m}^{3}$ (mean biomass $\pm 1 \mathrm{SE}=$ $7.15 \pm 0.01 \mathrm{~kg} / \mathrm{ha})$, similar to the peak density $\left(13.9 \mathrm{fish} / \mathrm{m}^{3}\right)$ in Kokosing Lake during 1988, but much lower than the 1987 peak (67.3 fish $/ \mathrm{m}^{3}$, see Results). To control for nutrient release in enclosures due to larval shad mortality (Threlkeld 1987), 100 dead larval gizzard shad (i.e. the number we expected a priori to die in enclosures due to handling stress, based on preliminary experiments) were added to each exclosure. On 7 June 1988 and weekly thereafter, zooplankton were sampled from the bags with a 2-m integrated tube sampler. Procedures for zooplankton sampling and processing were as for lake samples. Phytoplankton samples were collected from three randomly chosen enclosures and exclosures on 7 and 21 June 1988 (i.e. the beginning and midpoint of the experiment) by taking $100 \mathrm{~mL}$ of water from an integrated sample (collected using the 2-m tube sampler, but without filtering through the 54- $\mu \mathrm{m}$ net) and preserving with Lugol's preservative. These $100-\mathrm{mL}$ samples were concentrated $(20 \times)$ by settling for $24-48 \mathrm{~h}$ and two transects across a Sedgewick-Rafter cell were counted for each sample. On 5 July 1988, bags were drained using the large water pump; all fish were collected and preserved. All data were analyzed using ANOVA and repeated-measure ANOVA techniques (GLM procedure, SAS Institute Inc. 1985).

\section{Results}

\section{Field Pattern: Larval Gizzard Shad and Zooplankton}

Larval gizzard shad abundance peaked during late May to early June (Fig. 1A, 1E, and 7A-7D). Larvae were first captured during mid- to late May, with peak densities occurring 1-2 wk after first capture. Peak density varied between years, ranging from $14 \mathrm{fish} / \mathrm{m}^{3}$ during 1988 to $84 \mathrm{fish} / \mathrm{m}^{3}$ during 1986 (see Fig. A1, 1E, and 7A-7D).

Although crustacean zooplankton abundance differed between 1987 and 1988 (repeated-measures ANOVA, $F_{1,4}=$
$64.49, p=0.001)$, the overall pattern of a single peak during spring, followed by a dramatic decline, was similar in both years (Fig. 1B and 1F; the time $\times$ year interaction term was significant, $F_{20,80}=15.58, p=0.0002$, likely due to increasing abundance during October 1987). No single taxon dominated the crustacean zooplankton during either year, although copepod nauplii were numerically important during 1988 (Fig. 1C, and 1G). Rotifer abundance patterns, as well as absolute densities, varied between years (year effect, $F_{1,4}=$ $15.69, p=0.02$; time $\times$ year interaction, $F_{20,80}=18.92, p$ $=0.0002$ ). However, rotifer density did not consistently decline each year as did the crustacean zooplankton (Fig. 1D, and $1 \mathrm{H}$ ). In both 1987 and 1988, the period of most rapid zooplankton decline occurred within 2 wk of peak larval gizzard shad density.

Declining zooplankton abundance could be caused by decreased zooplankton reproduction as well as by increased predation due to young-of-year gizzard shad. To evaluate whether zooplankton reproduction was reduced during the period of declining density, we regressed an index of fecundity for Bosmina and Daphnia, the dominant cladocerans, on time during and just after the decline in zooplankton density in both years (22 May to 10 June 1987, 24 May to 27 June 1988; Fig. 1B, and 1F). The index was calculated as the product of the proportion of individuals that carried eggs and the mean number of eggs per individual carrying eggs. We included dates from during and just after the zooplankton decline, testing the null hypothesis that zooplankton reproduction declined during this period, contributing to the decline. The fecundity index for both taxa did not change during 1987 (Fig. 2A; linear regression, $p>0.08$ for both Bosmina and Daphnia). During 1988 the fecundity index declined for both taxa during the crustacean zooplankton crash (Fig. 2B; linear regression $p<0.01$ for both taxa).

\section{Enclosure/Exclosure Experiment}

Fish survival (exclusive of preexperiment handling mortality) varied across enclosures (ranging from 32 to $82 \%$ ), yielding densities at experiment's end of 6-15.5 fish $/ \mathrm{m}^{3}$ (mean $\pm 1 \mathrm{SE}$ $=10.9 \pm 1.4 \mathrm{fish} / \mathrm{m}^{3}$ ). Thus, a total of $89-108$ (from initial stocking to end) fish died in enclosures, similar to the 100 dead larval gizzard shad that were added to exclosures. In addition, two exclosures contained 1.5 and $5.5 \mathrm{fish} / \mathrm{m}^{3}$ at experiment's end. Because these bags were covered during the experiment and had no holes at draining, fish must have been introduced as exclosures were filled. Because fish were predicted to reduce zooplankton density, their presence in "exclosures" generates a conservative test; thus, data from these exclosures were included in all analyses as fish-exclosure data. At experiment's end, fish averaged $40.7 \pm 2.1 \mathrm{~mm} \mathrm{TL}$ (mean $\pm 1 \mathrm{SE}$ ), and final length was negatively related to final gizzard shad density (Fig. 3; linear regression, $F_{1,6}=16.88, p=0.006$ ). This relationship was significant regardless of whether data from the two exclosures with fish were included. Fish biomass in enclosures was $70.3 \pm 7.0 \mathrm{~kg} / \mathrm{ha}($ mean $\pm 1 \mathrm{SE}$, range $=40.3-94.2 \mathrm{~kg} /$ ha) at experiment's end.

Crustacean zooplankton density declined in enclosures relative to exclosures (Fig. 4A; repeated-measures ANOVA, treatment effect, $F_{1,10}=76.00, p=0.0001$; time $\times$ treatment interaction, $F_{4.40}=35.74, p=0.0001$ ); in fact, differences existed after only $2 \mathrm{wk}$, when zooplankton density in enclosures was reduced by 95\% (ANOVA, $F_{1,10}=39.55, p=$ $0.0001)$. Although initial crustacean zooplankton density was marginally higher in bags with fish than in the lake (ANOVA, 

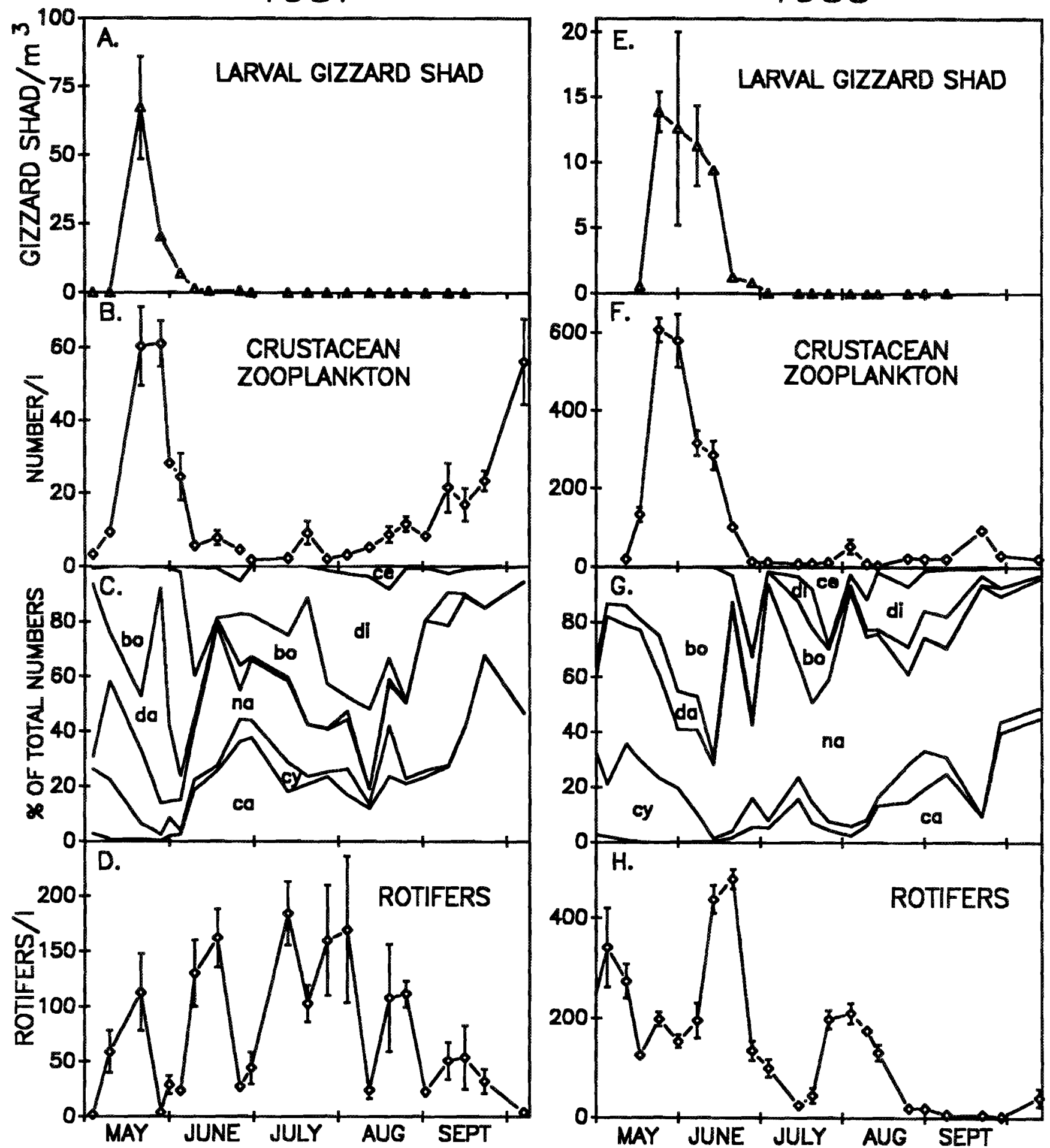

FiG. 1. Abundance of (A and E) larval gizzard shad and (B and F) crustacean zooplankton, ( $C$ and $G)$ crustacean zooplankton species composition, and (D and H) abundance of rotifers in Kokosing Lake, Ohio, during 1987 and 1988. Larval fish data are means \pm 1 sE from two replicate surface tows each week; zooplankton and rotifer data are means $\pm 1 \mathrm{SE}$ from three replicate integrated tube samples each week. Note different $y$-axis scales among panels. Abbreviations for zooplankton taxa: ca $=$ calanoid copepods, $c y=$ cyclopoid copepods, na $=$ copepod nauplii, $\mathrm{da}=$ Daphnia, bo $=$ Bosmina, $\mathrm{di}=$ Diaphanosoma, and $\mathrm{ce}=$ Ceriodaphnia .

$F_{1,7}=7.99, p=0.03, p$ required for significance $=(0.05 /$ $5)=0.01$ ), density declined similarly in the lake and enclosures (Fig. 4A; repeated-measures ANOVA, treatment effects $F_{1,7}=1.71, p=0.23$ ). Higher initial density in bags versus the lake occurred because bags excluded all planktivores for the
3 wk between filling and fish addition. Rotifer densities also declined in enclosures relative to exclosures (Fig. 4C; repeatedmeasures ANOVA, treatment effect, $F_{1,10}=26.76, p=$ 0.0004 ; treatment $\times$ time interaction, $F_{4.40}=19.58, p=$ 0.0001 ), differing between treatments 2 wk after fish introduc- 


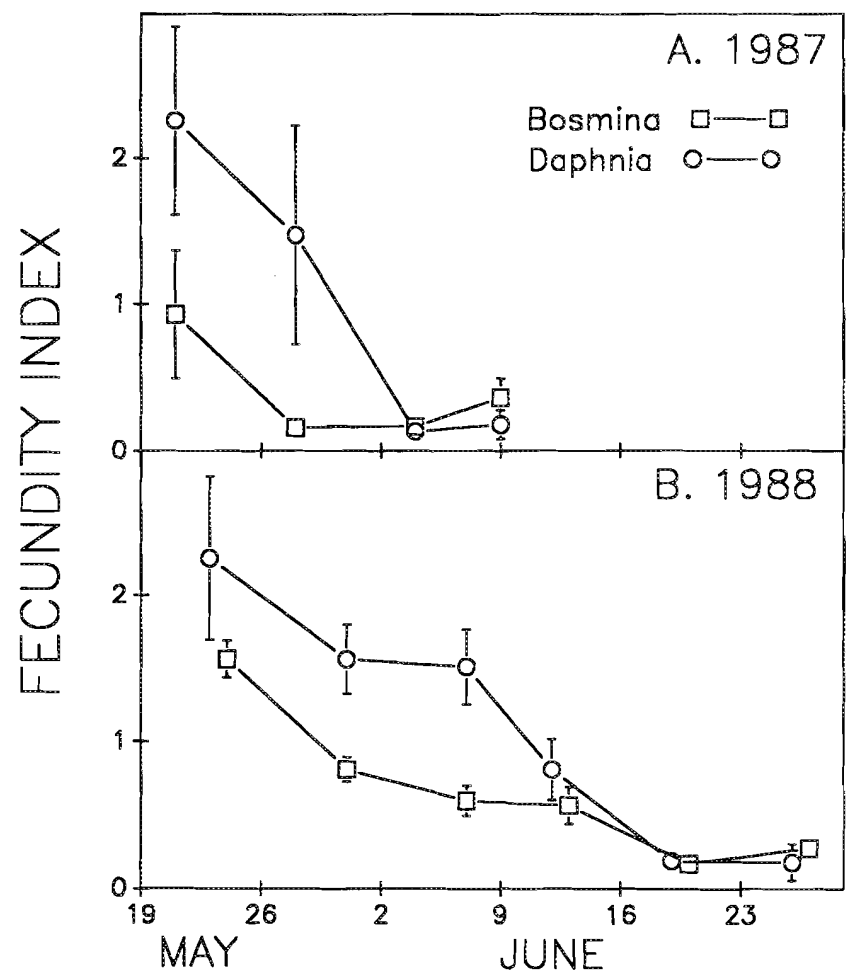

FIG. 2. Fecundity index for Bosmina (squares) and Daphnia (circles) in Kokosing Lake during the (A) 1987 and (B) 1988 zooplankton peaks and declines (22 May to 10 June 1987 and 24 May to 27 June 1988; see Fig. $1 \mathrm{~B}$ and $1 \mathrm{~F})$. The fecundity index was calculated as the product of the proportion of individuals carrying eggs $(n=50)$ and the mean number of eggs per individual carrying eggs $(n=20)$. Data are means \pm 1 sE from three replicate samples.

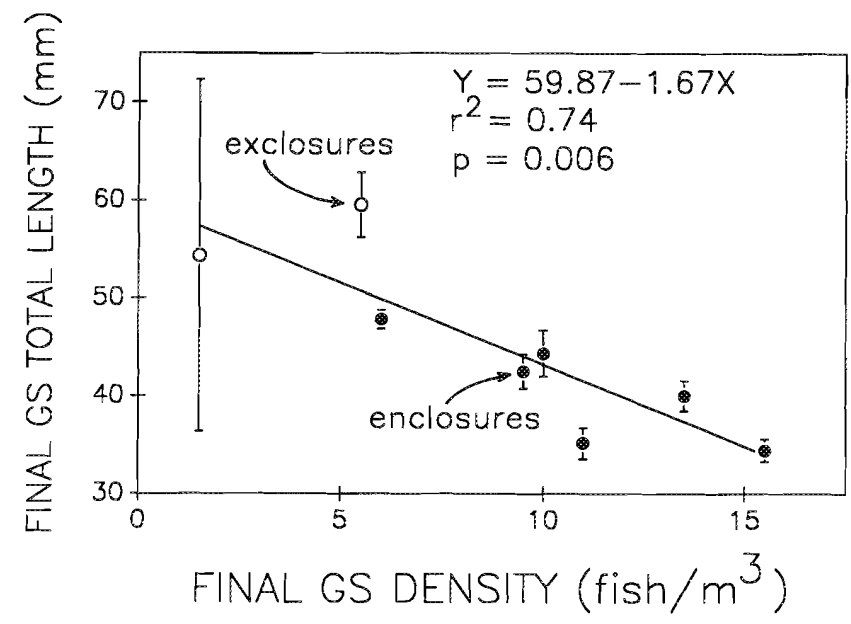

FIG. 3. Final size ( \pm 1 SE) of gizzard shad (GS) from the 1988 bag experiment in Kokosing Lake. Solid circles represent data from enclosures $(n=6)$ and open circles are from "exclosures" $(n=2$ of 6 exclosures) that had fish at the end of the experiment.

tion (Fig. 4C; ANOVA, $F_{1,10}=6.75, p=0.027$ ), a difference that became larger through time.

Crustacean zooplankton size differed between treatments (Fig. 4B; repeated-measures ANOVA, treatment effect, $F_{1,10}$ $=7.88, p=0.02$; treatment $\times$ time interaction, $F_{4,40}=6.82$, $p=0.002$ ). Size did not differ between treatments at the beginning or end of the experiment (ANOVAs, $p>0.11$ ), but zooplankton were smaller in enclosures 2 and $3 \mathrm{wk}$ after the fish addition (ANOVAs, $p<0.003$ ). However, zooplankton size

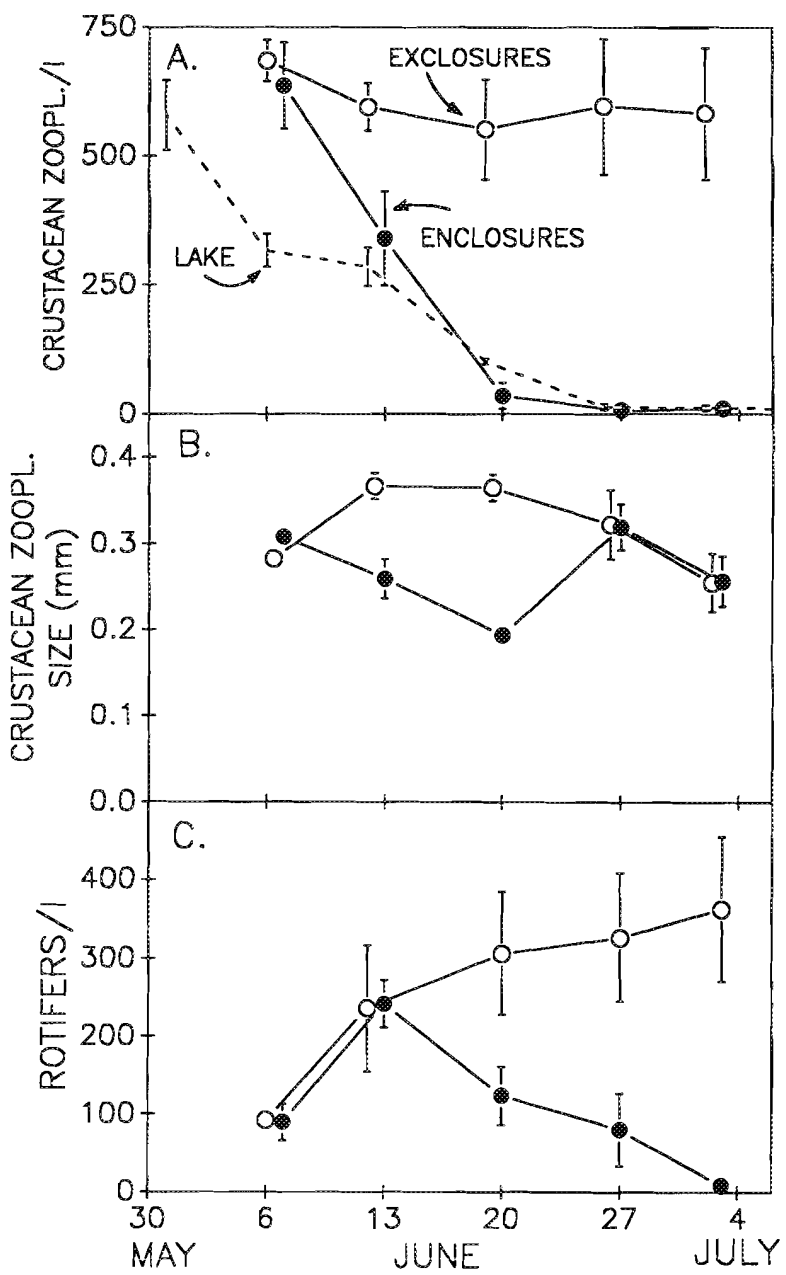

Fig. 4. (A) Density of crustacean zooplankton, (B) size of crustacean zooplankton, and (C) density of rotifers in enclosures (solid circles) and exclosures (open circles) from the 1988 bag experiment in Kokosing Lake. Included in Fig. 4A is crustacean zooplankton density from Kokosing Lake (broken line). Data are means \pm 1 sE from six replicates in bags and three replicates in the lake.

within taxa did not differ (repeated-measures ANOVA, treatment effects, all $p>0.07$ for Bosmina, Ceriodaphnia, Daphnia, calanoid copepods, cyclopoid copepods, and copepod nauplii).

As discussed earlier, declining zooplankton abundance could result from reduced zooplankton birth rates as well as from increased predation pressure by gizzard shad. For Bosmina, the only date on which mean fecundity differed between treatments was on 27 June 1988, when fecundity was higher in exclosures (Fig. 5A). Mean fecundity of Daphnia declined similarly in both treatments (repeated-measures ANOVA, time $\times$ treatment interaction, $F_{4,40}=0.85, p>0.48$ ) but was lower in enclosures than in exclosures (treatment effect, $F_{1,10}=6.07$, $p=0.03$ ) (Fig. 5B).

Volume of phytoplankton that was edible to zooplankton in the bags, primarily Cryptomonas, Cosmarium, Chroomonas, and very small cells, was reduced in enclosures relative to exclosures (Fig. 6; repeated-measures ANOVA, treatment effect, $F_{1.4}=12.55, p=0.02$; time $\times$ treatment interaction, $F_{1.4}=12.67, p=0.02$ ). However gizzard shad did not influence volume of inedible phytoplankton (primarily Oocystis, Pediastrum, Synedra, and Fragellaria; $p>0.17$ for both the treatment effect and the time $x$ treatment interaction). Because 


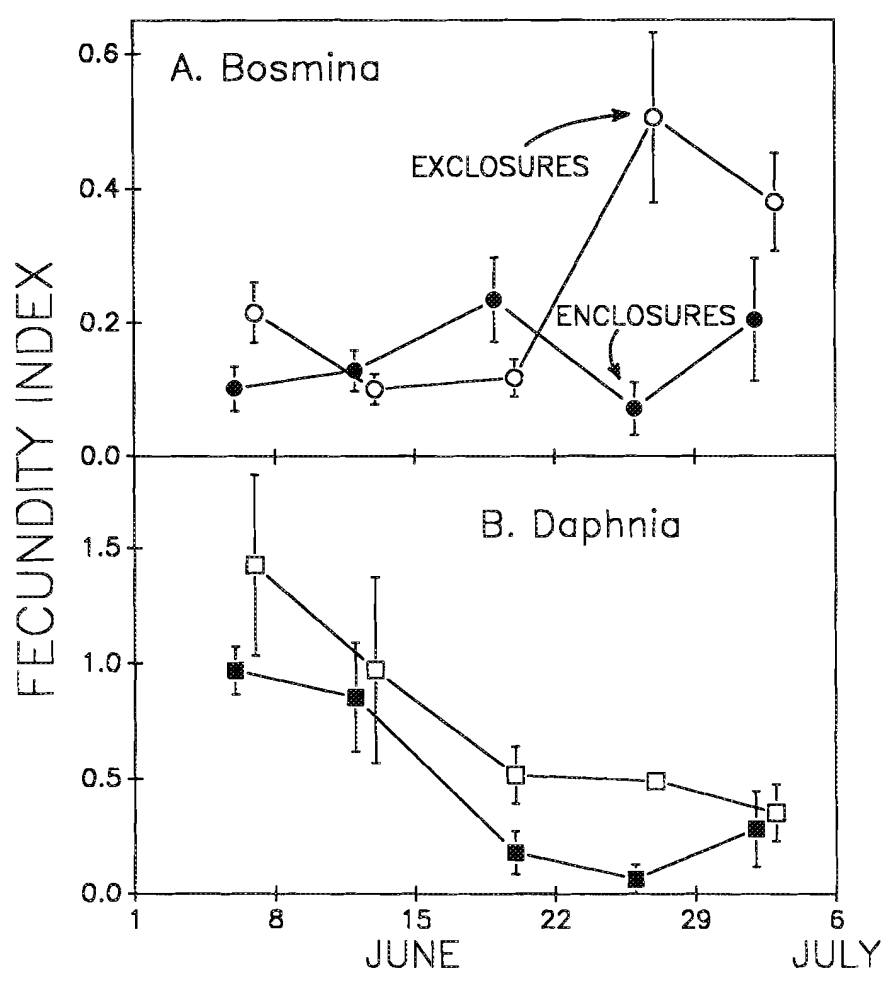

FIG. 5. Fecundity index for (A) Bosmina and (B) Daphnia in enclosures (solid symbols) and exclosures (open symbols) during the 1988 experiment in Kokosing Lake. The fecundity index is calculated as the product of the proportion of individuals carrying eggs and the mean number of eggs per individual carrying eggs. Data are means $\pm 1 \mathrm{SE}$ from six replicates.

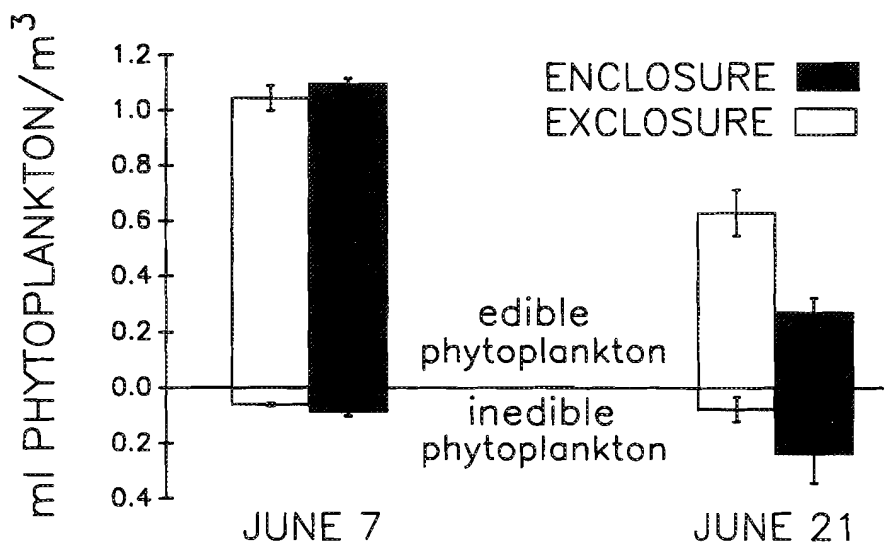

Fig. 6. Biovolume of edible and inedible phytoplankton in enclosures (solid bars) and exclosures (open bars) at the beginning (7 June 1988) and middle (21 June 1988) of the bag experiment in Kokosing Lake. Data are means $\pm 1 \mathrm{SE}$ from three replicates.

$75-90 \%$ of edible phytoplankton, at least on 7 June and in exclosures on 21 June, was Cryptomonas, the response of edible phytoplankton was due to a reduction in Cryptomonas in enclosures relative to exclosures. Using equations in Reynolds (1984) and assuming that carbon content equals $50 \%$ phytoplankton dry weight (Reynolds 1984), carbon content of edible phytoplankton in the bags was $0.200 \pm 0.008$ and $0.209 \pm$ $0.04 \mathrm{mg} / \mathrm{L}$ (mean $\pm 1 \mathrm{SE}$ ) in exclosures and enclosures, respectively, at the start of the experiment. On 21 June, $2 \mathrm{wk}$ into the experiment, carbon content was $0.121 \pm 0.016 \mathrm{mg} / \mathrm{L}$ in exclosures and $0.053 \pm 0.010 \mathrm{mg} / \mathrm{L}$ in enclosures.
Field Patterns: Larval Bluegill

Bluegill spawned for up to 3 mo of each year during 198689 , as documented by presence of limnetic larvae. Larval bluegill and gizzard shad typically overlapped in the limnetic zone for only 2-4 wk during each year of 1986-89 (Fig. 7). However, because bluegill spawned later than gizzard shad, larval bluegill initially arrived in the limnetic zone as crustacean zooplankton were declining precipitously (cf. Fig. $1 \mathrm{~B}$ and $1 \mathrm{~F}$ and $7 \mathrm{~B}$ and $7 \mathrm{C}$ ).

Small larval bluegill (i.e. $\leqslant 6.9 \mathrm{~mm}$ ) preferred small prey (nauplii and rotifers) during both years, while slightly larger fish $(7.0-9.9 \mathrm{~mm})$ showed no significant preference during 1987 and selected Bosmina during 1988 (Fig. 8). Bluegill $\geqslant 10 \mathrm{~mm}$ did not feed preferentially on any prey taxa during 1987, but selected Diaphanosoma during 1988 (Fig. 8). Variability in alphas was high, in part, because sample sizes were small, given that few bluegill were collected in offshore larval tows, particularly during 1987 .

Larval gizzard shad $<10 \mathrm{~mm}$ preferred copepod nauplii in both years, and fish 7.0-9.9 mm preferred cyclopoid copepods during 1988 (Fig. 8). Gizzard shad 10.0-12.9 mm showed no preference during 1987 and selected copepod nauplii and cyclopoid copepods during 1988. Fish $\geqslant 13.0 \mathrm{~mm}$ selected cyclopoid copepod and rotifers during both years (Fig. 8). In addition, phytoplankton was observed in larval gizzard shad diets, although poor preservation techniques for fish prohibited us from quantifying or identifying algae. Phytoplankton was never observed in larval bluegill diets. Overlap between larval bluegill and gizzard shad, measured using Schoener's index, and based only on zooplankton in fish diets (i.e. excluding phytoplankton), was $0.52 \pm 0.16$ (mean $\pm 1 \mathrm{SE}, n=4$ dates) during 1987 and $0.52 \pm 0.05$ (mean $\pm 1 \mathrm{SE}, n=3$ dates) during 1988.

To evaluate how larval fish responded to the decline of crustacean zooplankton, we quantified diets of $15-\mathrm{mm}$ gizzard shad (size held constant to control for changes in diet due to fish size) before, during, and after the decline during 1987 and 1988 . Because biomass of prey consumed by larval gizzard shad does not change during daylight hours (Dettmers and Stein 1992), biomass of prey in larval shad stomachs provides a relative estimate of consumption, based on a single collection. Diets were quantified from five dates during both years: two during the crustacean zooplankton peak, two during the decline, and one after the decline. Biomass of prey in larval gizzard shad stomachs differed across sample dates $\left(F_{4,40}=5.97, p=\right.$ 0.0007 ) and differed marginally between years (Fig. 9A; twoway ANOVA, year effect, $F_{1,40}=3.39, p=0.07$; year $\times$ date interaction, $F_{4,40}=4.23, p=0.006$ ). During 1987, prey biomass was greatest during peak crustacean zooplankton abundance and decreased as crustacean zooplankton density declined (ANOVA, $F_{4,20}=5.27, p=0.005$ ); however, during 1988, prey biomass did not differ across sample dates (ANOVA, $F_{4,20}$ $=1.92, p=0.15)$. Peak prey biomass differed marginally between years $\left(F_{1,8}=4.46, p=0.07\right)$. Further, the proportion of crustacean zooplankton in gizzard shad diets (the remainder being rotifers) decreased during and after the zooplankton crash in both years (Fig. 9B).

Based on these results, we predicted that the high peak densities of gizzard shad would lead to reduced crustacean zooplankton density, which, in turn, would reduce available food, growth, and, ultimately, recruitment of larval bluegill. Using data from $4 \mathrm{yr}$ of sampling (1986-89), total larval bluegill catch-per-effort (total number of bluegill collected divided by 

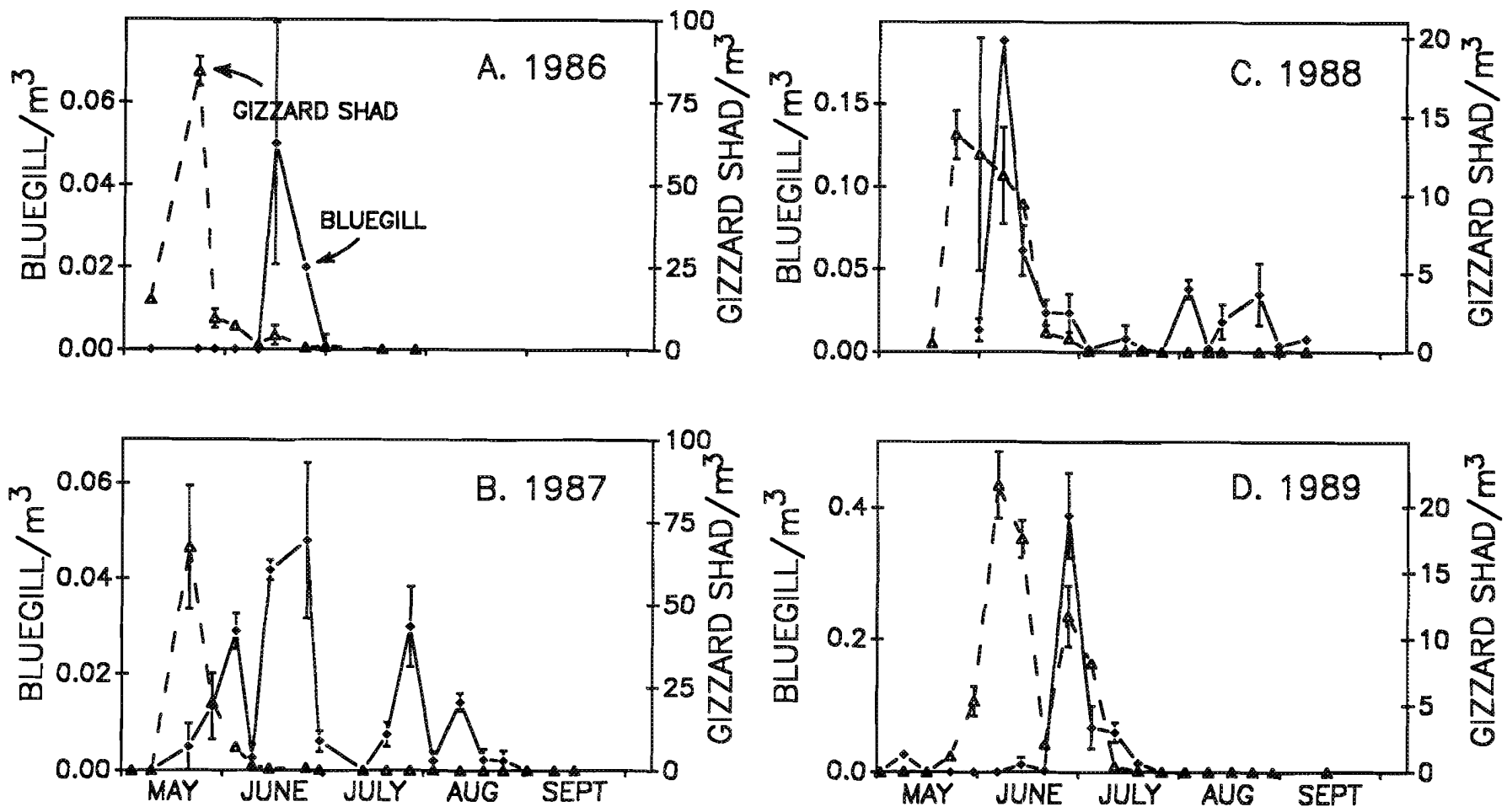

FIG. 7. Density of larval bluegill (solid diamonds, solid lines) and larval gizzard shad (open triangles, broken lines) for 1986-89. Note scale differences for the $y$-axes among panels.

total sampling time) was marginally related to peak larval gizzard shad density (Fig. 10; $F_{1,2}=13.72, p=0.066$ ).

\section{Discussion}

\section{Larval Gizzard Shad - Zooplankton Interactions}

Complex interactions among larval gizzard shad, zooplankton, and larval bluegill drive reservoir community dynamics during spring in Kokosing Lake. Via an enclosure/ exclosure experiment, we demonstrated that gizzard shad dramatically reduce crustacean zooplankton and then switch to rotifers shortly thereafter, in enclosures. In exclosures, densities of all zooplankton remained high. Patterns in the lake followed those in enclosures, suggesting that we mimicked lake conditions in this treatment.

At the start of the enclosure/exclosure experiment, fish in enclosures were of a size to be feeding as particulate planktivores (Drenner et al. 1982a; Lazzaro 1987). Consistent with the prediction that fish using this feeding mode should select large zooplankton, crustacean zooplankton were smaller in enclosures than in exclosures 1-2 wk after fish introduction. By the midpoint of the experiment, fish should have grown through a size at which they should begin filter feeding (i.e. $25 \mathrm{~mm}$; Drenner et al. 1982a). As filter feeders, gizzard shad consume large phytoplankton (i.e. Ceratium) as well as zooplankton that are most easily captured and will enhance small $(<70 \mu \mathrm{m})$ phytoplankton (Drenner et al. 1978, 1982a, 1982b, 1984, 1986; Drenner and McComas 1980; Threlkeld and Drenner 1987). Because crustacean zooplankton densities were nearly zero $2 \mathrm{wk}$ after fish introduction, we cannot evaluate whether more easily captured taxa were reduced at this point (i.e. when fish should have been $>25 \mathrm{~mm}$ ). However, phytoplankton in our experiment were depressed, rather than enchanced, in the presence of gizzard shad. Two factors are likely responsible for this reduced phytoplankton abundance with young-of-year gizzard shad. First, biomass of gizzard shad increased by an order of magnitude in enclosures; these growing fish may have incorporated sufficent nutrients into their growing bodies to limit growth of phytoplankton (Kitchell et al. 1975; C. Kraft, University of Wisconsin, Sea Grant Institute, pers. comm.). Such increases in biomass are well within the range of those observed from a variety of systems (average gizzard shad biomass $=101 \mathrm{~kg} / \mathrm{ha}$, Jenkins 1967 ; maximum biomass $=1236 \mathrm{~kg} / \mathrm{ha}$, Schoonover and Thompson 1954), suggesting that nutrient limitation may operate in the field. In addition, given that young-of-year gizzard shad in Kokosing Lake consumed phytoplankton, direct herbivory by young-of-year gizzard shad likely contributed to the phytoplankton decline (see also Iwata 1977; Juario and Storch 1984).

The zooplankton decline was associated with both increased predation on zooplankton (due to increased larval fish abundance) and a decline in the fecundity index (during one of the years). Upon becoming sufficiently abundant, zooplankton overgraze phytoplankton with a commensurate decline in fecundity (Lampert et al. 1986; reviewed in Sommer et al. 1986). However, this overgrazing seems unlikely in the enclosure/exclosure experiment. In fact, fecundities in exclosures with high zooplankton densities exceeded those in enclosures with low zooplankton densities. Predation, via selective removal of the more visible, egg-bearing individuals by larval gizzard shad, can reduce apparent birth rates (Gliwicz 1981). However, because zooplankter size within any taxon did not differ between treatments, gizzard shad did not shift zooplankton population structure toward nonreproductive (i.e. smaller) individuals. Alternatively, falling fecundity in the bags could be the result of reduced phytoplankton, driven to low levels by gizzard shad (via both herbivory and nutrient limitation; see above). Because phytoplankton carbon content in enclosures was reduced to below threshold levels required for egg production by most crustacean zooplankton (e.g. 


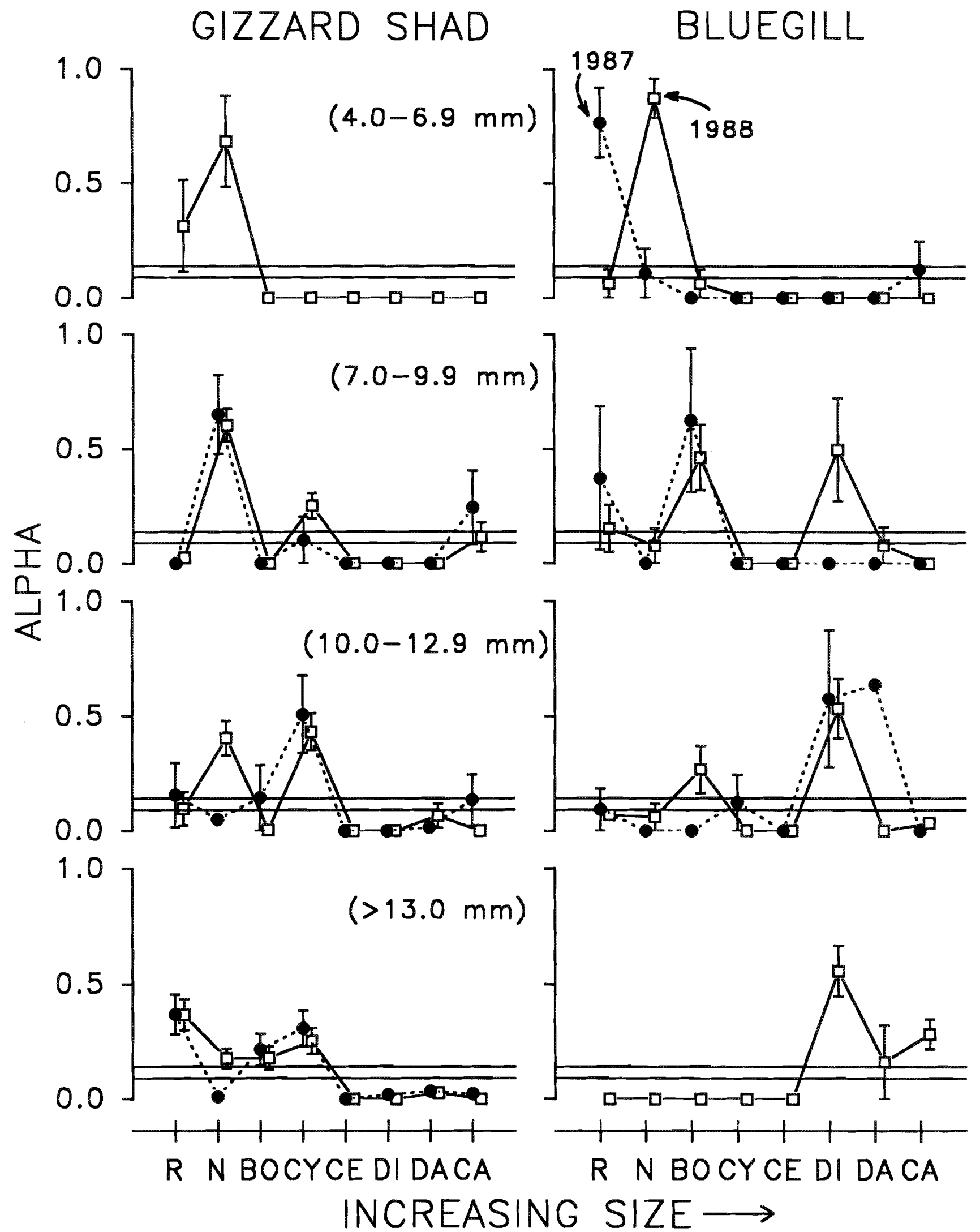

FIG. 8. Food selection (using Chesson's alpha, Chesson 1978, 1983) by larval gizzard shad and larval bluegill collected offshore in Kokosing Lake during 1987 (solid circles, broken lines) and 1988 (open squares, solid lines). Panels represent selection by different sizes of fish (4.0$6.9,7.0-9.9,10.0-12.9$, and $\geqslant 13.0 \mathrm{~mm}$ ). Data are presented as means \pm 1 SE. Prey taxa are ordered along the $x$-axis in increasing size from left to right. Abbreviations for zooplankton taxa: $\mathrm{R}=$ rotifers, $\mathrm{N}=$ copepod nauplii, $\mathrm{BO}=$ Bosmina, $\mathrm{CY}=$ cyclopoid copepods, $\mathrm{CE}=$ Ceriodaphnia, $\mathrm{DI}=$ Diaphanosoma, $\mathrm{DA}=$ Daphnia , and CA $=$ calanoid copepods. The horizontal lines indicate the region between 0.09 and 0.14 , the reciprocal of the range (7-11) bracketing the number of prey taxa in the lake; values above this range indicate positive selection, and values below this range indicate avoidance. Gizzard shad 4.0-6.9 mm did not contain food during 1987, and bluegill $\geqslant 13.0 \mathrm{~mm}$ were not collected during 1987. 

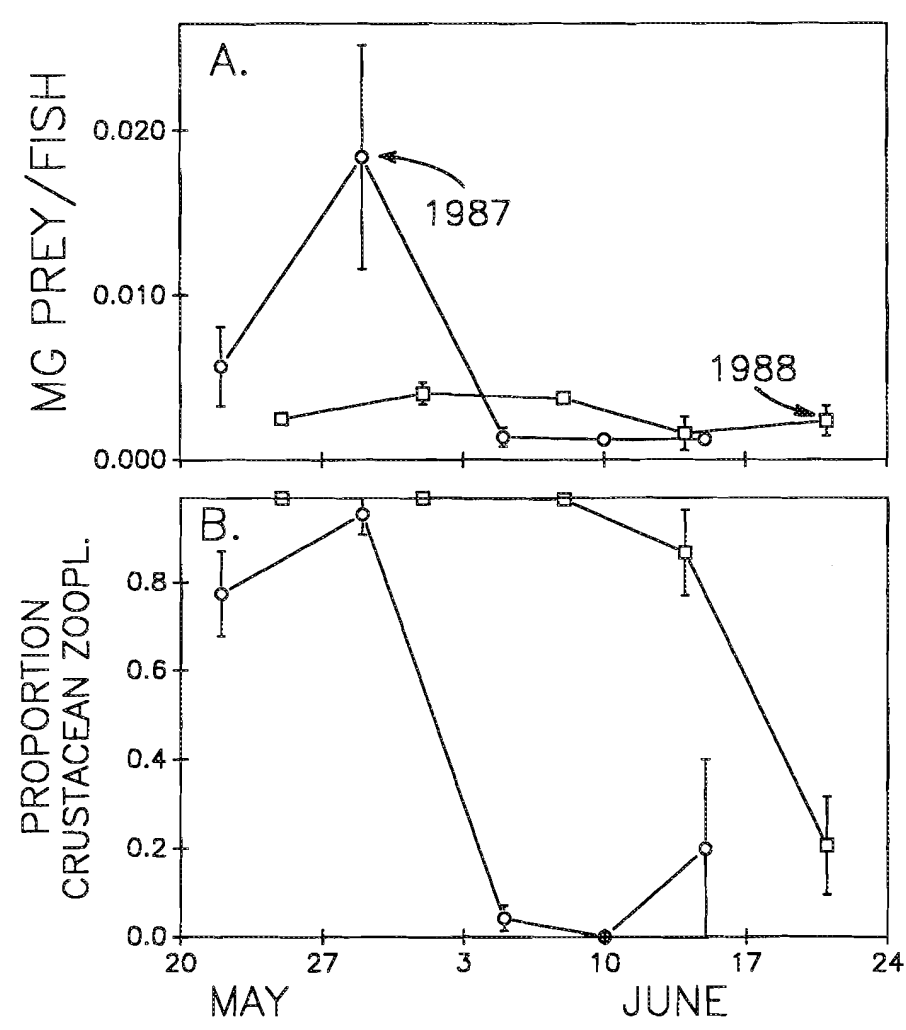

FiG. 9. (A) Mean prey biomass (dry weight) and (B) proportion (by numbers) of crustacean zooplankton in the diets of $15-\mathrm{mm}$ gizzard shad ( $n=5$ fish/date) before, during, and after the 1987 (circles) and 1988 (squares) zooplankton declines in Kokosing Lake.

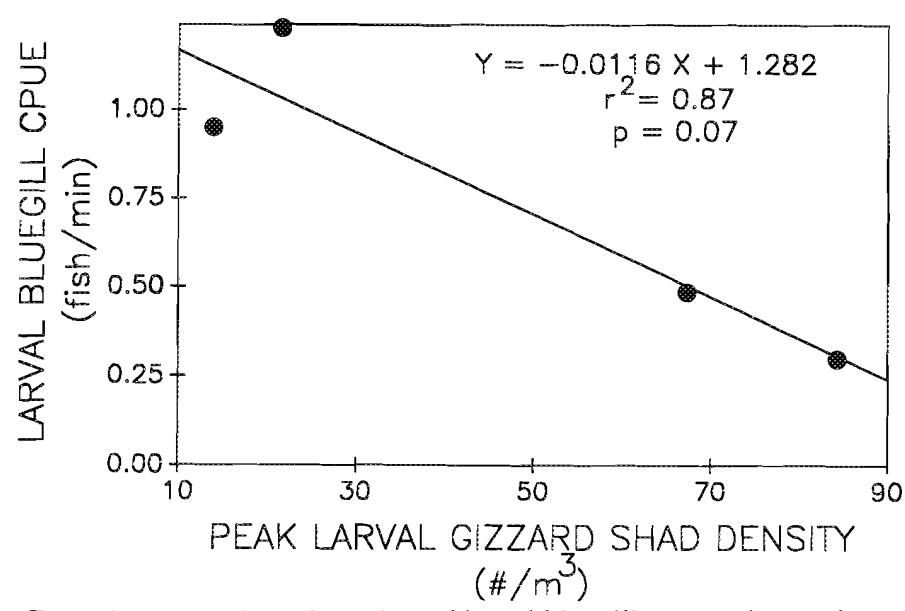

FIG. 10. Regression of number of larval bluegill captured per minute of larval fish tow (total number of bluegill caught per total sampling time) on peak larval gizzard shad density during 1986-89 in Kokosing Lake.

Lampert 1978; Gliwicz and Lampert 1990) and rotifers (Stemberger and Gilbert 1985), larval gizzard shad can simultaneously influence zooplankton both directly (i.e. predation) and indirectly (via their effects on phytoplankton). Although increased planktivore abundance typically leads to improved resources for zooplankton (Drenner et al. 1984; Lazzaro 1987), the direct and indirect effects of larval gizzard shad on zooplankton eliminated any indirect positive effects for phytoplankton.

Although peak larval gizzard shad densities in Kokosing Lake appear high relative to published values (e.g. 20-25 fish $/ \mathrm{m}^{3}$,
Mayhew 1977; $10 \mathrm{fish} / \mathrm{m}^{3}$, Downey and Toetz 1983; $\sim 4$ fish $/ \mathrm{m}^{3}$, Mathews 1984; $0.5 \mathrm{fish} / \mathrm{m}^{3}$, Tisa et al. 1985), final densities in the experiment $\left(6.0-15.5 \mathrm{fish} / \mathrm{m}^{3}\right)$, all of which produced zooplankton crashes, lie within published ranges. Crustacean zooplankton in "exclosures" with fish densities $<6 \mathrm{fish} / \mathrm{m}^{3} \mathrm{did}$ not crash; their densities at experiment's end were 96 organisms/L with $5.5 \mathrm{fish} / \mathrm{m}^{3}$ and 493 organisms $/ \mathrm{L}$ with $1.5 \mathrm{fish} / \mathrm{m}^{3}$. Consequently, at least in Kokosing Lake, gizzard shad densities must exceed this theshold to drive zooplankton to extinction (as is the case for the yellow perch (Perca flavescens) - Daphnia interaction, Mills et al. 1987). Variations in year-class strength of gizzard shad coupled with complex interactions among young-of-year gizzard shad, zooplankton, and phytoplankton yield fluctuations in gizzard shad abundance. These fluctuations around the threshold density necessary for a zooplankton decline may lead to systemwide effects and certainly contribute to the tremendous system variability so characteristic of small reservoirs (e.g. see papers in Iowa Conservation Commission and Sport Fishing Institute 1983).

\section{Effects on Larval Bluegill}

Over a 4-yr span, gizzard shad and bluegill densities were inversely related. Given that appropriate-sized prey of a minimum density are required for larval fish survival (e.g. see Lasker 1975; Noble 1975; Werner and Blaxter 1980; Mills and Forney 1981), exploitative competition by gizzard shad might reduce prey to levels below that requried by bluegill. Furthermore, slow growth could extend the period during which larvae are vulnerable to gape-limited predators (Rice et al. 1987a, 1987b). In either case, this inverse relation probably depends on relative spawning times. If bluegill spawned 2-4 wk earlier, their presence in the limnetic zone would occur during peak crustacean zooplankton abundance, perhaps leading to coexistence with gizzard shad. Conversely, if gizzard shad spawned 2-4 wk earlier, they would arrive in the limnetic before crustacean zooplankton peaked, possibly reducing gizzard shad success, as well as gizzard shad's impact on zooplankton and larval bluegill.

Despite the dramatic impact of larval gizzard shad on zooplankton, diet overlap between bluegill and gizzard shad was not high. During 1987, overlap values increased during May through June as crustacean zooplankton became sparse and rotifers dominated diets of both species; this pattern did not occur during 1988 when bluegill and gizzard shad co-occurred on five sampling dates. Because bluegill spawned after gizzard shad in Kokosing Lake, gizzard shad always were larger than bluegill and, as such, ate a diversity of prey items as compared with first-feeding bluegill, which were restricted to copepod nauplii and rotifers (as in Mallin et al. 1985). Thus, gizzard shad appear to influence bluegill via exploitative competition (as opposed to interference competition between shad and white crappie, as in Guest et al. 1990), driving crustacean zooplankton to low levels before bluegill began exogenous feeding.

Competition between gizzard shad and bluegill occurs even though adult diets do not typically overlap, i.e. gizzard shad eat detritus (Dendy 1946; Pahl and Maurer 1962; Baker and Schmitz 1971; Mundahl and Wissing 1987) whereas bluegill eat zooplankton and littoral invertebrates (Keast 1978; Mittelbach 1984). In fact, coexistence between these species may be facilitated by the storage effect (Chesson and Wamer 1981) because adult bluegill persist during those years when laval gizzard shad density is high and bluegill recruitment is low. However, interactions between young of these species have dra- 
matic consequences for coexistence as in bluegill-pumpkinseed (Lepomis gibbosus) interactions (Werner and Gilliam 1984; Mittelbach and Chesson 1987; Mittelbach 1988). As we include larval and juvenile life stages in our exploration of aquatic communities, more complex interactions such as these will likely be discovered.

Historically, abiotic factors have been emphasized relative to control of recruitment in fishes (Busch et al. 1975; Clady and Hutchinson 1975; Clady 1976; Beam 1983). However, recent work suggests that biotic factors contribute substantially to recruitment variability (Lasker 1975; Forney 1976; Werner and Blaxter 1980; Rice et al. 1987a, 1987b; Post and Prankevicius 1987). In Kokosing Lake, $87 \%$ of the year-to-year variability in bluegill recruitment was explained by variation in a biotic factor: peak larval gizzard shad density. In reality, several biotic mechanisms operate simultaneously through gizzard shad to influence bluegill recruitment, including direct competition (via predation on zooplankton) and indirect effects on zooplankton (see previous text).

The consequences of interaction between young-of-year gizzard shad and bluegill extend beyond bluegill recruitment, particularly because both gizzard shad and bluegill are forage species for piscivores (DeVries and Stein 1990). Gizzard shad recruitment varies independently of adult stock (Stock 1971), producing, we would argue, annual variation in zooplankton abundance, gizzard shad growth rates, and bluegill recruitment. Two factors that influence the susceptibility of prey to piscivores, bluegill recruitment and gizzard shad growth rates, vary with gizzard shad density, producing annual fluctuations in availability of prey to young-of-year largemouth bass. Because overwinter survival of young-of-year largemouth bass depends on body size and fat reserves in the fall (Adams et al. 1982), variations in prey availability ultimately will affect predator recruitment (see DeVries et al. 1991). Variation in recruitment alters adult population size, which, because fish are long-lived, will influence the aquatic community for many years, even decades in the future (Kitchell et al. 1988).

\section{Implications for the Tropic Cascade}

Gizzard shad are not controlled by fish predators owing to impressive fecundity (Bodola 1966; Wilder and Vondracek 1988; Parrish and Vondracek 1989), coupled with a narrow window of vulnerability to predators (Tisa et al. 1985; Johnson et al. 1988). Nor are they controlled by their zooplankton prey, for when zooplankton crash, gizzard shad switch to detritus and phytoplankton. We believe, therefore, rather than being regulated by top-down or botom-up forces, gizzard shad regulate community composition via "middle-out" processes. In Ohio reservoirs, gizzard shad drive complex interactions among fish (by reducing bluegill abundance, and hence largemouth bass recruitment, via intense planktivory as young-of-year, DeVries et al. 1991), crustacean zooplankton (virtually eliminating it by midsummer in some years), and phytoplankton (directly by herbivory and indirectly by controlling zooplankton and nutrient limitation). As opportunistic omnivores that dramatically influence community composition via middle-out activities, gizzard shad requires reservoir food-web interactions in a fashion inconsistent with the trophic cascade paradigm so characteristic of north temperate systems.

\section{Acknowledgements}

We thank E. Lewis, L. Ryan, H. Irvin, C. Mallison, J. Dettmers, and L. Einfelt for their help in the field and laboratory. We single out the efforts of $E$. Lewis, who was untiring in trips to the field, counting zooplankton, identifying and measuring larval fish, and quantifying fish diets. Dr. Susan Munch counted our phytoplankton samples. D. A. Culver contributed to our efforts to interpret our phytoplankton counts. Helpful comments were provided on an earlier draft of this manuscript by D. I. Berg, P. L. Chesson, K. R. Dabrowski, C. Luecke, W. M. Masters, and G. G. Mittelbach. Numerous conversations with $M$. J. Vanni, in addition to his critical review of this manuscript, helped us to better understand zooplankton-phytoplankton interactions. This work was funded in part by NSF BSR-8705518 and BSR-9107173 to RAS and BSR-9108986 to D.R.D., Federal Aid in Fish Restoration Project F-57-R to R.A.S. administered through the Ohio Division of Wildlife, and an O.S.U. Graduate Student Alumni Research Award to D.R.D.

\section{References}

Adams, S. M., R. B. MCLEAN, And M. M. HuffMan. 1982. Structuring of a predator population through temperature-mediated effects on prey availability. Can. J. Fish. Aquat. Sci. 39: 1175-1184.

Applegate, R. L., AND J. W. Mullan. 1967. Food of young largemouth bass, Micropterus salmoides, in a new and old reservoir. Trans. Am. Fish. Soc. 96: 74-77.

Balley, R. M., AND C. R. Robins. 1988. Changes in North American fish names, especially as related to the Intemational Code of Zoological Nomenclature, 1985. Bull. Zool. Nomencl. 45: 92-103.

BAKER, C. D., AND E. H. SCHMITZ. 1971. Food habits of adult gizzard shad and threadfin shad in two Ozark reservoirs, p. 3-11. In G. E. Hall [ed.] Reservoir fisheries and limnology. Spec. Publ. No. 8, American Fisheries Society, Washington, D.C.

BEAM, J. H. 1983. The effect of annual water level management on population trends of white crappie in Elk City Reservoir, Kansas. N. Am. J. Fish. Manage. 3: $34-40$

Bengtsson, J. 1987. Competitive dominance among Cladocera: are singlefactor explanations enough? Hydrobiologia 145: 245-257.

Bodola, A. 1966. Life history of the gizzard shad, Dorosoma cepedianum (LeSueur) in western Lake Erie. U.S. Fish Wildl. Serv. Fish. Bull. 65: $391-425$.

Brooks, J. L., AND S. I. DODSON. Predation, body size and composition of the plankton. Science (Wash., DC) 150:28-35.

Busch, W. D. N., R. L. Scholl, AND W. L. HaRTMan. 1975. Environmental factors affecting the strength of walleye (Stizostedion vitreum vitreum) year classes in western Lake Erie, 1960-70. J. Fish. Res. Board Can. 32: 1733-1743.

Carpenter, S. R. 1988. Complex interactions in lake communities. SpringerVerlag, New York, NY

CARPenter, S. R., J. F. Kitchell, AND J. R. Hodgson. 1985. Cascading trophic interactions and lake productivity. Bioscience $35: 634-639$.

Chesson, J. 1978. Measuring preference in selective predation. Ecology 59: 211-215.

1983. The estimation and analysis of preference and its relationship to foraging models. Ecology 64: 1297-1304.

CHESSON, P. L., AND R. R. WARNER. 1981. Environmental variability promotes coexistence in lottery competitive systems. Am. Nat. 117: 923-943.

ClADY, M. D. 1976. Influence of temperature and wind on the survival of early stages of yellow perch, Perca flavescens. J. Fish. Res. Board Can. 33: $1887-1893$.

Clady, M. D., and B. HutChinson. 1975. Effect of high winds on eggs of yellow perch, Perca flavescens, in Oneida Lake, New York. Trans. Am. Fish. Soc. 104: 524-525.

Cryer, M., G. Peirson, AND C. R. Townsend. 1986. Reciprocal interactions between roach, Rutilus rutilus, and zooplankton in a small lake: prey dynamics and fish growth and recruitment. Limnol. Oceanogr. 31: 10221038 .

Cushing, D. H. 1975. Marine ecology and fisheries. Cambridge University Press, Cambridge, England.

DEMOTT, W. R. The role of competition in zooplankton succession, p. 195 252. In U. Sommer [ed.] Plankton ecology: succession in plankton communities. Springer-Verlag, New York, NY.

DENDY, J. S. 1946. Food of several species of fish, Norris Reservoir, Tennessee. J. Tenn. Acad. Sci. 21: 105-127.

DETTMERS, J. M., AND R. A. STEIN. 1992. Food consumption by larval gizzard shad: zooplankton effects and its implications for reservoir communities. Trans. Am. Fish. Soc. (In press)

DEVRIES, D. R., AND R. A. STEIN. 1990. Manipulating shad to enhance sport fisheries in North America: an assessment. N. Am. J. Fish. Manage. 10 209-223. 
1991. Comparing three zooplankton samplers: a taxon-specific assessment. J. Plankton Res. 13: 53-59.

DeVries, D. R., R. A. Stein, J. G. Miner, and G. G. Mittelbach. 1991 Stocking threadfin shad: consequences for young-of-year fishes. Trans. Am. Fish. Soc. 120: 368-381.

Dodson, S. I. 1970. Complementary feeding niches sustained by size-selective predation. Limnol. Oceanogr. 15: 131-137.

1974. Zooplankton competition and predation: an experimental test of the size-efficiency hypothesis. Ecology 55: 605-613.

DOOLITTLE, W. L. 1982. The nature and cause of the midsummer decline of littoral zooplankton in Lake Itasca, Minnesota. Ph.D. dissertation, University of Tennessee, Knoxville, TN

DOWNEY, P., AND D. TOETz. 1983. Distribution of larval gizzard shad (Dorosoma cepedianum) in Lake Carl Blackwell, Oklahoma. Am. Midl. Nat. 109: 23-33.

DRENNER, R. W., DeNoyelles, F. JR., AND D. KetTLE. 1982a. Selective impact of filter-feeding gizzard shad on zooplankton community structure. Limnol. Oceanogr. 27: 965-968

DRENNER, R. W., AND S. R. MCCOMAS. 1980. The roles of zooplankter escape ability and fish size selectivity in the selective feeding and impact of planktivorous fish, p. 587-593. In W. C. Kerfoot [ed.] Evolution and ecology of zooplankton communities. University Press of New England, Hanover, $\mathrm{NH}$

Drenner, R. W. J. R. Mummert, F. DeNoyelles, JR., AND D. Kettle. 1984. Selective particle ingestion by a filter-feeding fish and its impact on phytoplankton community structure. Limnol. Oceanogr. 29: 941-948.

Drenner, R. W., W. J. O'Brien, AND J. R. MUMmert. 1982b. Filter-feeding rates of gizzard shad. Trans. Am. Fish. Soc. 111: 210-215.

DrenNer, R. W., J. R. STRICKLeR, AND W. J. O'Brien. 1978. Capture probability: the role of zooplankter escape in the selective feeding of planktivorous fish. J. Fish. Res. Board Can. 35: 1370-1373.

Drenner, R. W., S. T. ThrelKeld, AND M. D. MCCRACKen. 1986. Experimental analysis of the direct and indirect effects of an omnivorous filterfeeding clupeid on plankton community structure. Can. J. Fish. Aquat. Sci. 43: 1935-1945.

Ebenman, B., And L. Persson. 1988. Size-structured populations. SpringerVerlag, New York, NY.

Evans, M. S. 1986. Recent major declines in zooplankton populations in the inshore region of Lake Michigan: probable causes and implications. Can. J. Fish. Aquat. Sci. 43: 154-159.

FoRNEY, J. J. 1976. Year-class formation in the walleye (Stizostedion vitreum) population of Onedia Lake, New York. 1966-1973. J. Fish. Res. Board Can. 33: 783-792.

GLIWICZ, Z. M. 1981. Food and predation in limiting clutch size of cladocerans. Int. Ver. Theor. Angew. Limnol. Verh. 21: 1562-1566.

GLIWICZ, Z. M., AND W. LAMPERT. 1990. Food thresholds in Daphnia species in the absence and presence of blue-green filaments. Ecology 71: 691702 .

Gliwicz, Z. M., AND J. PijanowsKa. 1989. The role of predation in zooplankton succession, p. 253-296. In U. Sommer [ed.] Plankton ecology: succession in plankton communities. Springer-Verlag, New York, NY.

GOPHEN, M. 1990. Biomanipulation: retrospective and future development. Hydrobiologia 200/201: 1-11.

GREENE, C. H. 1985. Planktivore functional groups and patterns of prey selection in pelagic communities. J. Plankton Res. 7: 35-40.

GREGORY, R. S., AND P. M. POWLES. 1985. Chronology, distribution, and sizes of larval fish sampled by light traps in macrophytic Chemung Lake. Can. J. Zool. 63: 2569-2577.

Guest, W. C. R. W. Drenner, S. T. Threlkeld, F. D. Martin, and J. D. SMITH. 1990. Efffects of gizzard shad and threadfin shad on zooplankton and young-of-year white crappie production. Trans. Am. Fish. Soc. 119: 529-536.

Hall, D. J., S. T. Threlkeld, C. W. Burns, and P. H. Crowley. 1976. The size-efficiency hypothesis and the size structure of zooplankton communities. Annu. Rev. Ecol. Syst. 7: 177-208.

HANEY, J. F., AND D. J. HALl. 1973. Sugar-coated Daphnia: a preservation technique for Cladocera. Limnol. Oceanogr. 18: 331-333.

HaNSEN M. J., AND D. H. WAHL. 1981. Selection of small Daphnia pulex by yellow perch in Oneida Lake, New York. Trans. Am. Fish. Soc. 110: 64-71.

Iowa Conservation COMmission and Sport Fishing Institute. 1983. Pros and cons of shad. Iowa Conservation Commission, Des Moines, IA

IWATA, K. 1977. Morphological and physiological studies on the phytoplankton feeders of cyprinids II. Developmental changes of assimilation efficiency in terms of carbon, estimated by using 14C-labelled green algae in Carassius auratus cuvieri, Hypophthalmichthys molitrix and C. auratus grandoculis. Jpn. J. Limnol. 38: 19-32.
JENKINS, R. M. 1967. The influence of some environmental factors on standing crop and harvest of fishes in U.S. reservoirs, p. 298-321. In The American Fisheries Society [ed.] Reservoir fishery resources symposium. American Fisheries Society, Bethesda, MD.

Johnson, B. M., R. A. STein, and R. F. CARLine. 1988. Use of quadrat rotenone technique and bioenergetics modeling to evaluate prey availability to stocked piscivores. Trans. Am. Fish. Soc. 117: 127-141.

JUARIO, J. V., AND V. STORCH. 1984. Biological evaluation of phytoplankton (Chlorella sp., Tetraselmis sp. and Isochrysis galbana) as food for milkfish (Chanos chanos) fry. Aquaculture 40: 193-198.

KEAST, A. 1978. Feeding interrelationships between age groups of pumpkinseed sunfish (Lepomis gibbosus) and with the bluegill sunfish (L. macrochirus). J. Fish. Res. Board Can. 35: 12-27.

1980. Food and feeding relationships of young fish in the first weeks after the beginning of exogenous feeding in Lake Opinicon, Ontario. Environ. Biol. Fishes 5: 305-314.

KeRFOOT, W. C. 1987. Cascading effects and indirect pathways, p 57-70. In W. C. Kerfoot and A. Sih [ed.] Predation: direct and indirect impacts on aquatic communities. University Press of New England, Hanover, NH.

KERFOOT, W. C., AND A. SIH [ED.] 1987. Predation: direct and indirect impacts on aquatic communities. University Press of New England, Hanover, NH.

Kitchell, J. F., S. M. Bartell, S. R. Carpenter, D. J. Hall, D. \&. McQueen, W. E. NeIll, D. Scavia, and E. E. Werner. 1988. Epistemology, experimentation, and pragmatism, p. 263-280. In S. R. Carpenter [ed.] Complex interactions in lake communities. Springer-Verlag, Berlin, Germany.

Kitchell, J. F., J. F. KoonCE, AND P. S. Tennis. 1975. Phosphorus flux through fishes. Verh. Int. Ver. Limnol. 19: 2478-2484.

LAMPERT, W. 1978. A field study on the dependence of the fecundity of Daphnia on food concentration. Oecologia 36: 363-369.

LAMPERT, W., W. FleCKNER, H. RAI, AND B. E. TAYloR. 1986. Phytoplankton control by grazing zooplankton: a study on the spring clear-water phase. Limnol. Oceanogr. 31: 478-490.

LASKER, R. 1975. Field criteria for survival of anchovy larvae: the relation between inshore chlorophyll maximum layers and successful first feeding. Fish. Bull. 73: 453-462.

LAZZARO, X. 1987. A review of planktivorous fishes: their evolution, feeding behaviours, selectivities, and impacts. Hydrobiologia 146: 97-167.

LYNCH, M. 1979. Predation, competition, and zooplankton community structure: an experimental study. Limnol. Oceanogr. 24: 253-272.

MALLIN, M. A., L. J. BiRChFIELD, AND W. WARREN-Hicks. 1985. Food habits and diet overlap of larval Lepomis spp. and gizzard shad in a Piedmont reservoir. Proc. Annu. Conf. SE Assoc. Fish Wildl. Agencies 39: 146155 .

MATTHEWS, W. J. 1984. Influence of turbid inflows on vertical distribution of larval shad and freshwater drum. Trans. Am. Fish. Soc. 113: 192-198.

MAYHEW, J. 1977. The effects of flood management regimes on larval fish and fish food organisms at Lake Rathbun. Iowa Fish. Res. Tech. Ser. No. 77-2, lowa Conservation Commission, Des Moines, IA.

MCQuEEN, D. J. 1990. Manipulating community structure: where do we go from here? Freshwater Biol. 23: 613-620.

MCQueen, D. J., M. R. S. Johannes, J. R. Post, T. J. Stewart, and D. R. S. LEAN. 1989. Bottom-up and top-down impacts of freshwaer pelagic community structure. Ecol. Monogr. 59: 289-309.

MILLS, E. J., AND J. L. ForNEY. 1981. Energetics, food consumption, and growth of young yellow perch in Oneida Lake, New York. Trans. Am. Fish. Soc. 110: $479 m 488$.

1988. Trophic dynamics and development of pelagic food webs, p. 11-30. In S. R. Carpenter [ed.] Complex interactions in lake communities. Springer-Verlag, Berlin, Germany.

Mills, E. L., J. L. ForNEY, AND K. J. WAGNER. 1987. Fish predation and its cascading effect on the Oneida Lake food chain, p. 118-131. In W. C. Kerfoot and A. Sih [ed.] Predation: direct and indirect impacts on aquatic communities. University Press of New England, Hanover, NH.

MrTtelBACH, G. C. 1981. Foraging efficiency and body size: a study of optimal diet and habitat use by bluegills. Ecology 62: 1370-1386.

1984. Predation and resource partitioning in two sunfishes (Centrarchidae). Ecology 65: 499-513.

1988. Competition among refuging sunfishes and effects of fish density on littoral zone invertebrates. Ecology 69: 614-623.

Mrttelbach, G. G., and P. L. Chesson. 1987. Predation risk: indirect effects on fish populations, p. 315-332. In W. C. Kerfoot and A. Sih [ed.] Predation: direct and indirect impacts on aquatic communities. University Press of New England, Hanover, NH.

MundaHL, N. D., AND T. E. Wissing. 1987. Nutritional importance of detritivory in the growth and condition of gizzard shad in an Ohio reservoir. Environ. Biol. Fishes 20: 129-142 
NOBLE, R. L. 1975. Growth of young yellow perch (Perca flavescens) in relation to zooplankton populations. Trans. Am. Fish. Soc. 194: 731-741.

NoRThCOTE, T. G. 1988. Fish in the structure and function of freshwater ecosystems: a "top-down" view. Can. J. Fish. Aquat. Sci. 45: 361-379.

PAHL, B. G., AND J. MAURER. 1962. Food habits of the young gizzard shad. Proc. Minn. Acad. Sci. 31: 20-21.

PARRish, D. L., AND B. VondraCEK. 1989. Population dynamics and ecology of Lake Erie gizzard shad. Project F-61-R-2 Annu. Perf. Rep., Ohio Department of Natural Resources, Columbus, $\mathrm{OH}$.

Post, J. R., AND A. B. PRANKEviCIUS. 1987. Size-selective mortality in youngof-the-year yellow perch (Perca flavescens): evidence from otolith microstructure. Can. J. Fish. Aquat. Sci. 44: 1840-1847.

REYNoLDS, C. S. 1984. The ecology of freshwater phytoplankton. Cambridge University Press, Cambridge, England.

RICE, J. A., L. B. CROWDER, AND F. P. BINKOWSKI. 1987a. Evaluating potential sources of mortality for larval bloater (Coregonus hoyi): starvation and vulnerability to predation. Can. J. Fish. Aquat. Sci. 44: 467-472.

RICE, J. A., L. B. CROWDER, AND M. E. Holey. 1987b. Exploration of mechanisms regulating larval survival in Lake Michigan bloater: a recruitment analysis based on characteristics of individual larvae. Trans. Am. Fish. Soc. 116: 703-718

Rosentmal, H., AND G. HEMPEL. 1970. Experimental studies in feeding and food requirements of herring larvae (Clupea harengus L.), p. 344-364. In J. H. Steel [ed.] Marine food chains. University of California Press, Berkeley, CA.

SAS INSTITUTE INC. 1985 SAS users guide: statistics. Version 5 ed. SAS Institute Inc., Cary, NC.

SCHOENER, T. W. 1970. Non-synchronous spatial overlap of lizards in patchy habitats. Ecology 51: 408-418.

SCHOONOVER, R., AND W. H. ThOMPSON. 1954. A post-impoundment study of the fisheries resources of Fall River Reservoir, Kansas. Trans. Kans. Acad. Sci. 57: 172-179.

SHAPIRO, J., AND D. I. WRIGHT. 1984. Lake restoration by biomanipulation: Round Lake, Minnesota, the first two years. Freshwater Biol. 14: 371383.

Sommer, U., Z. M. Geiwicz, W. Lampert, and A. Duncan. 1986. The PEG model of seasonal succession of planktonic events in fresh waters. Arch. Hydrobiol. 106: 433-471.

Stemberger, R. S., AND J. J. Gilbert. 1985. Body size, food concentration, and population growth in planktonic rotifers. Ecology 66: 1151-1159.

STOCK, J. N. 1971. A study of some effects of population density on gizzard shad and bluegill growth and recruitment in ponds. M.S. thesis, University of Missouri, Columbia, MO

Storck, T. W., D. W. Dufford, and K. T. Clement. 1978. The distribution of limnetic fish larvae in a flood control reservoir in central Illinois. Trans. Am. Fish. Soc. 107: 419-424.

THRELKELD, S. T. 1987. Experimental evaluation of trophic-cascade and nutrient-mediated effects of plankrivorous fish on plankton community structure, p. 161-173. In W. C. Kerfoot and A. Sih [ed.] Predation: direct and indirect impacts on aquatic communities. University Press of New England, Hanover, NH.

ThreLKELD, S. T., AND R. W. DRENNER. 1987. An experimental mesocosm study of residual and contemporary effects of an omnivorous, filter-feed- ing, clupeid fish on plankton community structure. Limnol. Oceanogr. 32: 1331-1341.

Timmons, T. J., W. L. Shelton, and W. D. Davies. 1978. Initial fish population changes following impoundment of West Point Reservoir, Alabama-Georgia. Proc. Annu. Conf. SE Assoc. Fish Game Comm. 31: 312-317.

TISA, M. S., J. J. NEY, AND D. K. WhITEHURST. 1985. Spatial and temporal distribution of larval alewives and gizzard shad in a Virginia reservoir. Proc. Annu. Conf. SE Assoc. Fish Wildl. Agencies 39: 65-73.

Wallace, R. K. JR. 1981. An assessment of diet-overlap indexes. Trans. Am. Fish. Soc. 110: 72-76.

WARE, D. M. 1980. Bioenergetics of stock and recruitment. Can. J. Fish. Aquat. Sci. 37: 1012-1024.

WARSHAW, S. J. 1972. Effects of alewives (Alosa pseudoharengus) on the zooplankton of Lake Wononskopomuc, Connecticut. Limnol. Oceanogr. 17: $816-825$.

WeLLS, L. 1970. Effects of alewife predation on zooplankton populations in Lake Michigan. Limnol. Oceanogr. 15: 556-565.

WERNER, E. E., AND J. F. GILlIAM. 1984. The ontogenetic niche and species interactions in size-structured populations. Annu. Rev. Ecol. Syst. 15: $393-425$.

Werner, E. E., J. F. Gilliam, D. J. Hall, and G. G. Mimtelbach. 1983 An experimental test of the effects of predation risk on habitat use in fish Ecology 64: 1540-1548.

WERNER, R. G. 1967. Intralacustrine movements of bluegill fry in Crane Lake, Indiana. Trans. Am. Fish. Soc. 96: 416-420.

1969. Ecology of limnetic bluegill (Lepomis macrochirus) fry in Crane Lake, Indiana. Am. Midl. Nat. 81: 164-181.

WERNER, R. G., AND J. H. S. BLAXTER. 1980. Growth and survival of larval herring (Clupea harengus) in relation to prey density. Can. J. Fish. Aquat. Sci. 37: 1063-1069.

WHITESIDE, M. C. 1989.0 + fish as major factors affecting abundance patterns of littoral zooplankton. Int. Ver. Theor. Angew. Limnol. Verh. 23: 17101714.

Whiteside, M. C., W. L. Doolitrle, AND C. M. Swindoll. 1985a. Zooplankton as food resource for larval fish. Int. Ver. Theor. Angew. Limnol. Verh. 22: 2523-2526.

Whiteside, M. C., C. M. SWINDOLl, AND W. L. DoOLITtLe. 1985b. Factors affecting the early life history of yellow perch, Perca flavescens. Environ. Biol. Fishes 12: 47-56.

Wilder, I. B., AND B. VONDRACEK. 1988. Population dynamics and ecology of Lake Erie gizzard shad. Project F-61-R-1 Annu. Perf. Rep., Ohio Department of Natural Resources, Columbus, $\mathrm{OH}$.

Wong, B., AND F. J. WARD. 1972. Size selection of Daphnia pulicaria by yellow perch (Perca flavescens) fry in West Blue Lake, Manitoba. J. Fish. Res. Board Can. 29: 1761-1764.

WONG, C. K. 1981. Predatory feeding behaviour of Epischura lacustris (Copepoda: Calanoida) and prey defense. Can. J. Fish. Aquat. Sci. 38: 275279.

ZARET, T. M. 1980. Predation and freshwater communities. Yale University Press, New Haven, CT. 